\title{
A recurrent cyst hydatic abscess fistulised to the bronchial tree
}

\author{
Bronşiyal ăgaca fistülize olan nüks kist hidatik absesi \\ Kamuran Cumhur Değer*, Tahsin Dalgı̧̣, Murat Ulaş, Erdal Birol Bostancı, \\ Canbek Seven, Musa Akoğlu
}

Clinic of Gastroenterological Surgery (K. C. Değer, MD, T. Dalgıç, MD, M. Ulaş, MD, Prof. E. B. Bostanc1, MD, C. Seven, MD, Prof. M. Akoğlu, MD), Türkiye Yüksek İhtisas Hospital TR-06100 Ankara

\begin{abstract}
Human cystic echinococcosis is a zoonosis transmitted by ingesting Ecchinococcus granulosus ova eliminated from infected dogs. A 41-year-old man was admitted to the hospital with symptoms of abdominal tenderness located in the epigastric region, fever and vomiting. .We diagnosed a recurrent hydatic disaese and after admission to our hospital he began to cough with greenyellowish colored sputum with abscess. Posteroanterior chest X-ray and right pleural US revealed no fluid collection but right lower lung atelectasis and diaphragma elevation. With these results we performed an operation for broncho-biliary fistula. He was discharged from the hospital on the ninth postoperative day. Careful assessment and early treatment of septic complications are essential in the successful treatment of this rare condition.
\end{abstract}

Keywords: Bronchobiliary fistula, echinococcosis

\section{Özet}

Ekinokoka bağlı kist hidatik hastalığı enfekte olmuş köpeklerin dışkısından alınan echinocococcus granulosus yumurtasının sindirilmesi ile geçer. 41 yaşında bir erkek hasta epigastrik bölgede olan hassasiyet, ateş ve kusma ile hastanemize kabul edildi. Yapılan tetkikler sonucunda nüks kist hidatik absesi teşhisi konularak yatırılan hasta tedavi altında iken abse içeriği olan sarı-yeşil renkte balgamlı öksürmeye başladı. PA akciğer grafisinde ve sağ plevral US'de sıvı saptanmadı ve sağ akciğer alt lob atelektazisi ve diyafram elevasyonu tespit edildi. Bu bulgularla bronkobiliyer fistül tanısıyla hasta ameliyata alındı. Postoperatif dokuzuncu günde hasta taburcu edildi. Bu nadir görülen durumun başarılı tedavisi için septik komplikasyonların dikkatli değerlendirme ve erken tedavisi önem arz etmektedir.

Anahtar sözcükler: Bronkobiliyer fistül, ekinokokkozis

Geliş tarihi/Received: November 07, 2011; Kabul tarihi/Accepted: December 04, 2012

*Corresponding author:

Dr. Kamuran Cumhur Değer, Gastroenteroloji Cerrahisi Kliniği, Türkiye Yüksek İhtisas Hastanesi, TR-06100 Ankara. E-mail: cumhurdeger@hotmail.com

\section{Introduction}

Human cystic echinococcosis is a zoonosis transmitted by ingesting Ecchinococcus granulosus ova eliminated from infected dogs. A broncho-biliary fistula (BBF) is defined as an abnormal communication between the biliary system and the bronchial tree due to trauma, hemihepatectomy and necrotic hepatic infections, such as hydatid disease [1-3]. Several factors participate in promoting intrathoracic evolution of hydatid cysts of the hepatic dome. 
1. The intrathoracic negative pressure tends to aspirate the hepatic hydatid cyst.

2. The mechanical compression maintained by the cyst on the diaphragm results in local ischemia, which can lead to muscle erosion.

3. Sepsis in the hepatic cyst can also contribute to muscle necrosis close to the cyst.

4. In the case of biliary fistulas, the caustic property of biliary secretions can lead to chemical erosion of the diaphragm and the bronchi.

For hydatid disease that fistulised to the thoracic cavity a classification had been established by Mestiri and colleagues, which was improved by Dévé (Table 1) [4]. According to this classification our case was a type 1 bronchobiliary fistula. In this report, we describe a case of bronchobiliary fistula in a man with recurrent hydatid disease abscess that was treated via laparotomy.

Table 1. Classification established by Mestiri and colleagues, which improves on that proposed by Dévé.

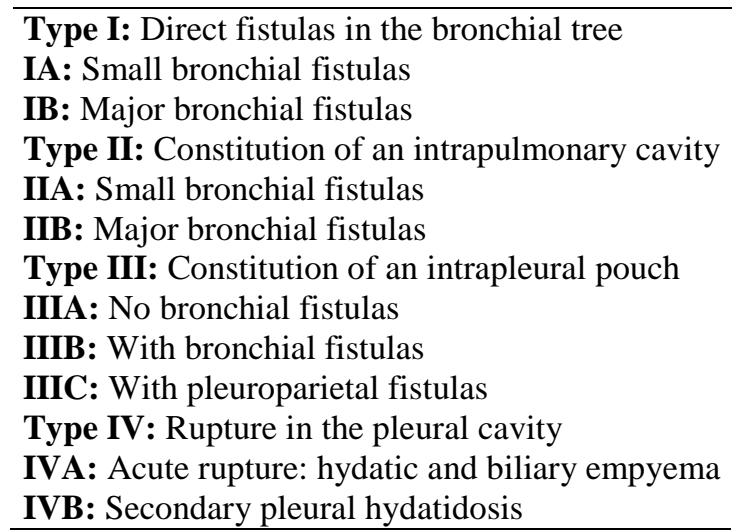

\section{Case report}

A 41-year-old man was admitted to the hospital with symptoms of abdominal tenderness located in the epigastric region, fever and vomiting. Ultrasonography (US) and abdominal computerized tomography (CT) demonstrated a hydatid cyst recurrence at the dome of the liver nearly $12 \times 10 \mathrm{~cm}$ in size (Figure 1a) and abscess with air-fluid level (Figure 1b). The patient underwent an operation for hydatic disease in another hospital 5 months ago. After this operation because of the persistence of symptoms 3 months later, an endoscopic retrograde cholangiopancreatography (ERCP) with sphinceterotomy and puncture, aspiration, injection, and reaspiration (PAIR) was performed. Two months after these efforts, the patient presented to our hospital with the symptoms as described above. We hospitalised the patient and initiated systemic antibiotics. 2 days after admission he began to cough with greenyellowish colored sputum with abscess. The temperature of the patient was $38.1^{\circ} \mathrm{C}$. No jaundice was detected, but there was mild tenderness in the right quadrant. Laboratory studies revealed increased levels of alkaline phosphatase, bilirubin, and white cell count.

Posteroanterior chest X-ray (Figure 2) and right pleural US revealed no fluid collection but right lower lung atelectasis and diaphragma elevation. With these results we performed an operation for BBF. The exploration findings was a cyst hydatid abceess pouch that had germinative membrane in it and this membrane penetrated to the pleural space (Figure 3). The cyst pouch was cleaned with scolocidal material and germinative membrane was excised, the diaphragmatic defect was primary repaired with tube thoracostomy.He was discharged from the hospital on the ninth postoperative day without any complication. 


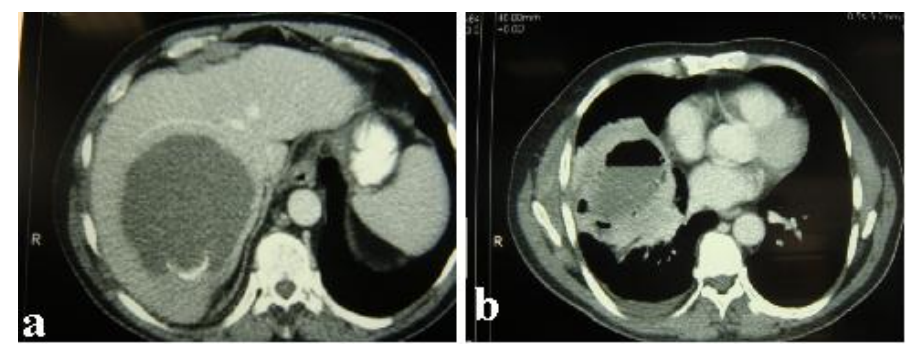

Figure 1a. Hydatid cyst recurrence at the dome of the liver nearly $12 \times 10 \mathrm{~cm}$ in size and (b) abscess with air-fluid level.

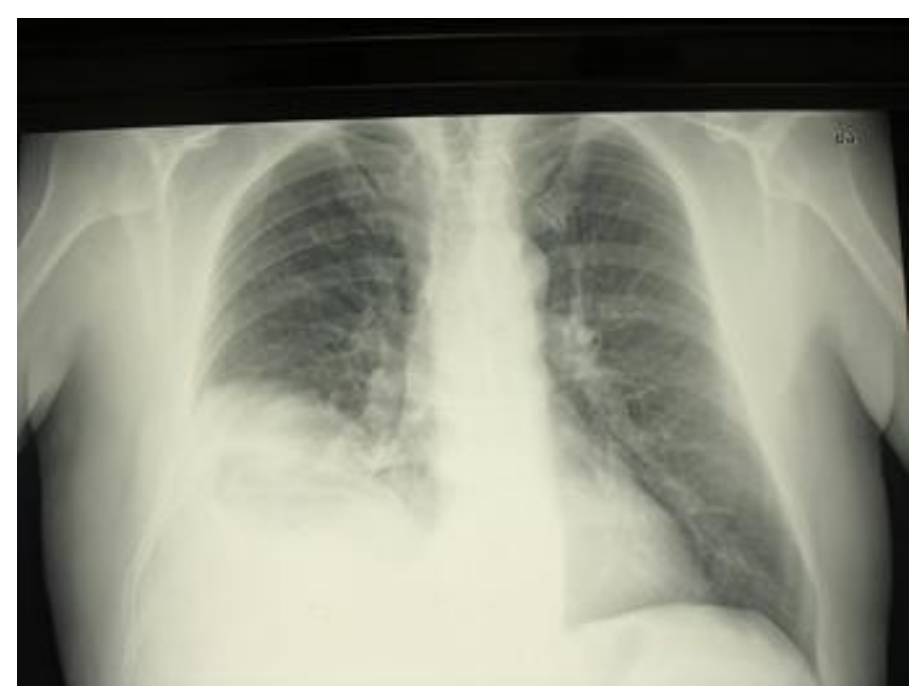

Figure 2. Posteroanterior chest $\mathrm{X}$-ray revealing right lower lung atelectasis and diaphragma elevation.

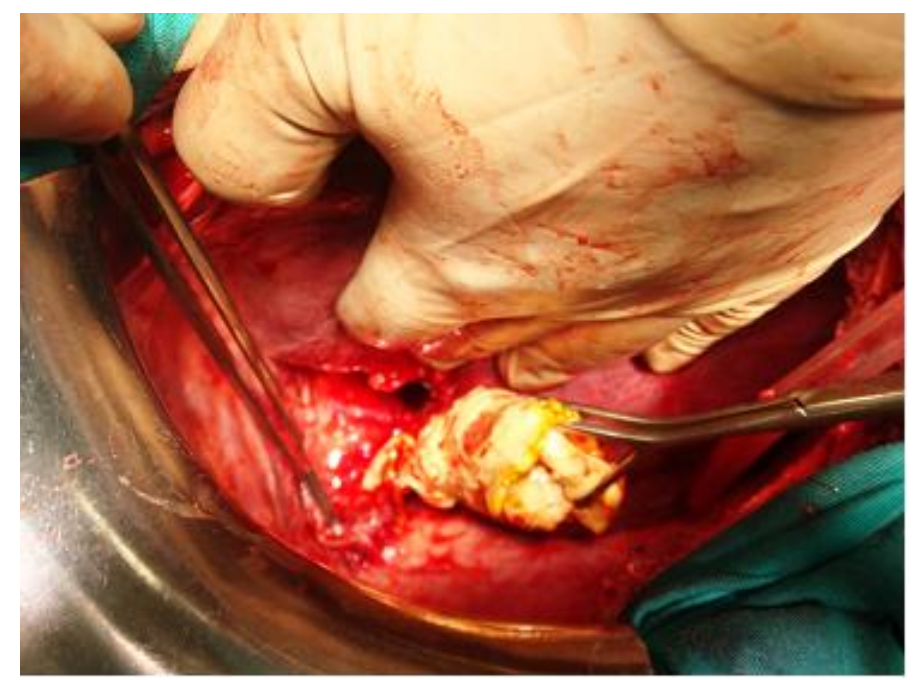

Figure 3. Peroperative findings of the cyst hydatid abceess pouch that had germinative membrane in it and this membrane had penetrated to the pleural space.

\section{Discussion}

Hydatid disease is endemic in Turkey, with high rates of infection (1/20.000-1/50.000) [1] one of the main complications of the hydatid cyst of the dome of the liver is its rupture into the bronchial tree $[3,5]$. This occurs due to a combination of pressure erosion 
from an expanding hydatid cyst to the diaphragm and the destructive effect of superimposed infection. If enough adhesions precede the erosion, the cyst will rupture into the pulmonary parenchyma causing pneumonitis and BBF [3, 6]

In many series, bronchography is not considered to be a useful diagnostic tool; we also didn't perform it to our patient. Today there are less invasive methods such as CT scan, ultrasonography and nuclear imaging that turned to be very important diagnostic tools [7, 8]. Management has traditionally been surgical resection, but recently embolization of the fistula [9] and stent placement to relieve common bile duct obstruction have been described [10]. Surgery still remains the treatment of choice in case of echinococcosis $[11,12]$. BBF is a complicated surgical problem because it is characterised by a complex of pathological lesions involving organs in continuity in the thoracic and abdominal cavities as well as the interposed diaphragm. The characteristics of the primary cystic lesions, the site and seriousness of diaphragmatic and pulmonary secondaries, and the frequency of biliary complications affect our surgical approach to BBF [13].

Many authors are in favour of a transpleural approach. It gives a good exposure and the lung complications can be treated. If abdominal complications occur the incision can be extended to the abdomen or a separate abdominal incision made [14].

We do not agree with this opinion. Any radical treatment of the cyst attempted via standard thoracotomy is unsafe because of lack of control of the hepatic pedicle, inferior vena cava, and hepatic veins, and results in serious intraoperative risks. In our case we performed a surgical approach via laparotomy that would be less morbid for the patient. The BBF was type 1 according to Dévé's classification and after the disconnection of the fistula we thought that the patient would benefit from this intervention.

Thoracoabdominal incision is rarely reported in the literature because it is thought to cause increased morbidity [15]. Thoracoabdominal approach (TA) provides a view of the entire complex of the BBF. The section of the diaphragm provides simultaneous control of both the diaphragmatic surfaces and facilitates the blunt dissection of the diaphragm adhering to the cyst and to the lung. TA gives good access to the hepatic pedicle and to the biliary tract, enabling haemostatic manouvres, intra-operative cholangiography and any required surgical procedure on the biliary tract. Since 1990 thoracic portion of TA has been performed among the fifth or seventh intercostal space because it provides better access to the principal and segmental hila of the right inferior lobe of the lung. The choice of the route of access and the surgical technique should not depend on the surgeon's preference, but rather be tailored to the requirements posed by the site, nature, and extent of disease.

A risk of delaying treatment is rupture of the lung cyst with widespread pulmonary soiling and acute respiratory failure. Careful assessment and early treatment of septic complications are essential in successfully treating this rare condition.

\section{References}

1. Johnson MM, Chin R Jr, Haponik EF. Thoracobiliary fistula. S Med J 1996; 89: 335-9.

2. Senturk H, Mert A, Ersavasti G, Tabak F, Akdogan M, Ulualp K. Bronchobiliary fistula due to alveolar hydatid disease: report of three cases. Am J Gastroenterol 1998; 93: 2248-53.

3. Yacoubian HD. Thoracic problems associated with hydatid cysts of the dome. Surgery 1976; 79: 544-8.

4. Kilani T, Daoues A, Horchani H, Sellami M. Place of thoracotomy in thoracic complications of hydatid cysts of the liver. Ann Chir 1991; 45: 705-10.

5. Gómez R, Moreno E, Loinaz C, De la Calle A, Castellon C, Manzanera M, Herrera V, Garcia A, Hidalgo M. Diaphragmatic or transdiaphragmatic thoracic involvement in hepatic hydatid disease: surgical trends and classification. World 
J Surg 1995; 19: 714-9.

6. Borrie J, Shaw JH. Hepatobronchial fistula caused by hydatid disease. The Dunedin experience 1952-79. Thorax 1981; 36: 25-8.

7. Warren KW, Christophi C, Armendariz R, Basu S. Surgical treatment of bronchobiliary fistulas. Surg Gynecol Obstet 1983; 157: 351-6.

8. Bretland PM. Biliary-bronchial fistula due to old hydatid cyst demonstrated with Tc-HIDA. Br J Radiol 1983; 56: 757-9.

9. D'Altorio RA, McAllister JD, Sestric GB, Cichon PJ. Hepatopulmonary fistula: treatment with biliary metallic endoprosthesis. Am J Gastroenterol 1992; 87: 7846.

10. Sharma BC, Agarwal N, Garg S, Kumar R, Sarin SK. Endoscopic management of liver abscesses and cysts that communicate with intrahepatic bile ducts. Endoscopy 2006; 38: 249-53.

11. Athanassiadi K, Kalavrouziotis G, Loutsidis A, Bellenis I, Exarchos N. Surgical treatment of echinococcosis by a transthoracic approach: a review of 85 cases. Eur J Cardiothorac Surg 1998; 14: 134-140.

12. Freixinet JL, Mestres CA, Cugat E, Mateu M, Gimferrer JM, Catalán M, Callejas MA, Letang E, Sánchez-Lloret J. Hepaticothoracic transdiaphragmatic echinococcosis. Ann Thorac Surg 1988; 45: 426-9.

13. Tocchi A, Mazzoni G, Miccini M, Drumo A, Cassini D, Colace L, Tagliacozzo S. Treatment of hydatid bronchobiliary fistulas: 30 years of experience. Liver Int 2007; 27: 209-14.

14. Xanthakis DS, Katsaras E, Efthimiadis M, Papadakis G, Varouchakis G, Aligizakis C. Hydatid cyst of the liver with intrathoracic rupture. Thorax 1981; 36: 497-501.

15. Sakhri J, Ben Ali A, Letaief R, Derbel F, Dahmen Y, Ben Hadj Hmida R. Hydatic cysts of the liver ruptured into the thorax. Diagnostic and therapeutic aspects. J Chir 1996; 133: 437-41. 